Discussion

\title{
Synchrony between the Central Atlantic magmatic province and the Triassic-Jurassic mass-extinction event? Reply to Marzoli et al.
}

\author{
Jessica H. Whiteside ${ }^{\mathrm{a}, *}$, Paul E. Olsen ${ }^{\mathrm{b}}$, Dennis V. Kent ${ }^{\mathrm{b}, \mathrm{c}}$, Sarah J. Fowell ${ }^{\mathrm{d}}$, Mohammed Et-Touhami ${ }^{\mathrm{e}}$ \\ a Department of Geological Sciences, Brown University, 324 Brook Street, Box 1846, Providence RI 02912, USA \\ b Department of Earth and Environmental Sciences, Lamont-Doherty Earth Observatory of Columbia University, 61 Route, Palisades, NY 10964, USA \\ c Department of Geological Sciences, Rutgers University, Piscataway, NJ 08554, USA \\ d Department of Geology and Geophysics, University of Alaska Fairbanks, Fairbanks, AK 99775, USA \\ e LGVBS, Département des Sciences de la Terre, Université Mohamed Premier, 60, 000, Oujda, Morocco
}

\section{A R T I C L E I N F O}

Article history:

Received 25 January 2008

Received in revised form

31 January 2008

Accepted 14 February 2008

\section{Keywords:}

Triassic

Jurassic

CAMP

Volcanism

Mass extinction

We are very pleased with the attention, long overdue, that the Triassic-Jurassic boundary and associated events, such as the CAMP, are receiving. This can only lead to greater specificity of hypotheses and greater understanding in the long run, and it is worth emphasizing some broad areas of agreement.

Marzoli et al. (2008-this volume) points out the closeness in time of CAMP and Tr-J extinctions, and on this we all agree. We also agree that the systematic differences among different isotopic systems used for dating is a challenge to determining the relative timing of events dated with different techniques. This problem, however, seem to be fading as high-precision single-crystal U-Pb dates $\left({ }^{206} \mathrm{~Pb} /{ }^{238} \mathrm{U}\right)$ are available from a variety of tuffs interbedded with marine strata as well as the North Mountain Basalt of Nova Scotia, which lies above the palynological Triassic-Jurassic extinction event in Nova Scotia. Schoene et al. (2006) obtained an age of 201.27 \pm 0.03 Ma from this basalt, which is very close to an age of $201.5 \mathrm{Ma}$ for a tuff $1 \mathrm{~m}$ above the last local occurrence of the topmost Triassic guide-fossil, the ammonite Choristoceras in a marine section in Peru (Schaltegger et al., 2007), presumably very close to the Triassic-Jurassic extinction event. Schaltegger et al. (2007) also obtained an age of 199.5 Ma for the

DOI of original article: 10.1016/j.palaeo.2005.11.039.

* Corresponding author. Tel.: +1 401863 6465; fax: +1 4018632058.

E-mail address: Jessica_Whiteside@brown.edu (J.H. Whiteside).
Hettangian-Sinemurian boundary from the latter section. Consistent with these ages, Pálfy and Mundil (2006) obtained ages of 200.6 \pm 0.3 Ma for an ash layer in ammonite-bearing Middle Hettangian marine sediments in, Alaska, and 198.0 \pm 0.6 Ma for a tuff layer in Early Sinemurian sediments in Hungary. These dates are not compatible with the multi-crystal age for the Triassic-Jurassic boundary of 199.6 \pm 0.3 Ma of Pálfy and Mundil (2006), a fact recognized by Pálfy and Mundil (2006). Thus, we are in complete agreement that the TriassicJurassic extinction event is extremely close in time to the onset of the CAMP. The question is, "are any of the known flows of the CAMP actually at or before this extinction event?". That is the key issue dealt with by Whiteside et al. (2007), and it is a possibility that we recognize as completely plausible, but not yet demonstrated.

It is in that spirit of general agreement that we reply to Marzoli et al.'s, comment. We note, however, that their comment touches on far too many points to adequately address in this reply, and we chose to focus our response on their most substantive issues, recalling that our paper was focusing on the testable aspects of their overall hypothesis. We deal with their criticisms in the order they present them.

\section{Magnetostratigraphy}

The key evidence reiterated by Marzoli et al. (2008-this volume) to argue that CAMP activity started before and may thus have contributed to the end-Triassic extinctions are the observations of samples with opposite (reverse) polarity in basalts of the Central High Atlas (CHA): 1) by Marzoli et al. (2004) in the Tiourjdal section of a "brief reversal" in a "localized interlayered limestone bed interstratified in the ... 260-m-thick basaltic pile"; and 2) by Knight et al. (2004) in the Oued Lahr section of another reverse direction in a single pillow lava at a different relative horizon. There are three problems with their interpretations of these reverse intervals.

First, Marzoli et al. (2008-this volume) state that their "one single or two distinct" intervals in Morocco are most easily correlated to latest Triassic Chron E23r of the Newark basin (Kent and Olsen, 1999) and polarity intervals SA5n.3r and SA5r of the St. Audrie's Bay section (Hounslow et al., 2004), rather than with the early Jurassic polarity reversals in the Paris basin Montcornet core (Yang et al., 1996). We fail to understand this logic because their argument violates the principle 
of transitivity, in that Chron E23r cannot be both polarity intervals A5n.3r and SA5r and one or two brief reversals in Morocco.

Second, of the 60 polarity chrons found in the 5000-m-thick 30-Mylong Newark succession, Chron E23r, which occurs only 20 ky before the (palynologically-defined) Triassic-Jurassic boundary, is the shortest ( $10 \mathrm{ky}$ ) chron according to cycle stratigraphy (Kent and Olsen, 1999). This brevity of Chron C23r would make it generally difficult to find, especially in a relatively small series of lava flows that represent a small number of instantaneous readings of the paleofield with the recorder off the vast majority of the time. Moreover, the estimated duration of E23r is so short that it virtually precludes the possibility that it might consist of two separate polarity intervals, since it takes several thousand years for the geomagnetic field to reverse polarity (Clement, 2004).

Third, although we can confirm what Marzoli et al. (2008-this volume) inferred from results reported in abstract, that the first polarity reversals detected in the Early Jurassic section of the Hartford basin occur more than 1.6 My after the Triassic-Jurassic boundary (Kent and Olsen, in press), and reversals have not yet been found in the CAMP extrusive zones of any of the Newark Supergroup basins of eastern North America, this does not discount the presence of five thin intervals with reverse paleomagnetic directions in Hettangian sediments - 3 in the basal, 1 in the middle, and 1 in the late Hettangian - in the Montcornet core from the Paris Basin (Yang et al., 1996), which is the most detailed magnetostratigraphic marine record for the Early Jurassic. A short duration of 2-3 My for the Hettangian is indicated by new single-crystal zircon $\mathrm{U}-\mathrm{Pb}$ dates in biostratigraphically-controlled marine deposits by Pálfy and Mundil (2006) and Schaltegger et al. (2007). Therefore, compared to the astronomically-calibrated geomagnetic polarity time scale from the Hartford basin (Kent and Olsen, in press), which encompasses the first 2.4 Myr of the Jurassic, the three short reversals found in basal Hettangian marine sediments in the Montcornet core (Yang et al., 1996) are likely to occur in close in time to Chron E24n and plausibly during CAMP igneous activity. Although these very short polarity intervals or excursions, if real, have yet to be confirmed in the CAMP extrusive zone in the Newark basins, it may be that one (or two?!) of them have in fact been serendipitously found in the CAMP lava sections from the Moroccan High Atlas region by Marzoli et al. (2004) and Knight et al. (2004) and perhaps even in the St. Audrie's Bay section of Hounslow et al. (2004). This alternative strikes us as no less plausible and in fact more parsimonious than the correlation(s) to Chron E23r suggested by Marzoli et al. (2004), but our alternative interpretation has a very different implication with regard to the relative timing of CAMP igneous activity and end-Triassic extinctions.

\section{Palynology}

Marzoli et al. (2008-this volume) seems to be arguing that there is significant uncertainty in the identification of the Triassic-Jurassic boundary in the Fundy basin at Partridge Island. This seems an odd point, given that the argument of Marzoli et al. (2004) hinges on the assumption that Partridge Island sections in fact represents the boundary. If it is not the boundary then the position of all of the basalts relative to the Triassic-Jurassic boundary is unknown and their entire argument would seem to be moot.

We again point out that this is the very same section described in detail by Fowell and Traverse (1995) with many photographs. We presented no photographs of specimens in our new samples because our data confirm that of Fowell and Traverse (1995), and in any case we are documenting an extinction event, not an appearance event, and the taxa we argue indicate a Triassic age are not disputed: a photograph of a taxon not present is not very useful. In addition, Cirrelli (pers. comm., 2007) has stated that she was able to duplicate observations of Fowell and Traverse (1995) and Whiteside et al. (2007) at this locality.

Marzoli et al. (2008-this volume) also claim that the new data we presented from the Argana basin were undocumented but the taxa present are uncontroversial, and photographs cannot document the absence of Patinasporites in the uppermost sample. Marzoli et al. (2004) do have the Triassic guide pollen taxon, Patinasporites, in their uppermost levels in their sections from the Argana basin, but their photographs of their sections show the rockss are obviously deformed (Fig. 2 of the text and Fig. 1 of the supplemental material, of Marzoli et al., 2004). This deformation leads us to argue that the uppermost strata in their sections may be structurally omitted. In short, the "plastic" deformation cited by Marzoli et al. (2008-this volume) as evidence of a lack of a hiatus, is evidence to us of possible structural omission. We also have data from other basins in Morocco in which Patinasporites is present in the uppermost productive samples below the basalts, but in all these cases there is a near-bedding-parallel fault between the sediments and the basalt and the sections are likely not complete. Indeed, in their sections, the absence of any metamorphic aureole, which we find is present in all of the intact sections, suggests that there may be some structural omission of section. Nonetheless, Marzoli et al. (2008-this volume) are correct in noting that there are other reasons than extinction that Patinasporites may be absent from the section, but at the same time there are also reasons, such as reworking, for the presence of taxa above the level they actually went extinct. We are talking about intervals that are centimeters thick in sections several kilometers thick, and at some level surely reworking very well might be problem. In any case it is a moot point, because unless Patinasporites is found above the Argana basalt, which it has not been, we do not know if the top of its range ended before the basalt (our argument) or above it (their argument).

Marzoli et al. (2008-this volume) also make a point of noting that uniquely Jurassic taxa are not known from the Nova Scotian or Moroccan strata we interpret as Jurassic. It is important to recognize that among the expectations of a catastrophic mass extinction is that the initial post-extinction taxa would be survivors from earlier times. Characteristically, as at the Permo-Triassic and the CretaceousTertiary boundary, guide fossils of the post-extinction time interval do not generally appear until higher levels. Accordingly, asking for uniquely Jurassic taxa, after the extinction event, is asking for a phenomenon not expected of a catastrophic mass extinction, which is presumably what Marzoli et al. (2008-this volume) is attempting to explain by the CAMP eruptions in the first place. The same basic pattern of survivorship is seen at the Triassic-Jurassic transition in Jameson Land in East Greenland in both palynology and especially macroflora (Dam and Surlyk, 1993; McElwain Popa et al., 2007).

Biostratigraphic arguments of Kozur and Weems (2005) based on conchostracans are cited by Marzoli et al. (2008-this volume) to argue that what is identified palynologically as the Triassic-Jurassic boundary may be within the Triassic, but they fail to spell out the full implications. In fact, Kozur and Weems (2005) argue the dark shale bed immediately below Chron E23r is Norian (!), consistent with van Veen's (1995) notion that there is a large hiatus at the palynological extinction level in the Newark basin. But if this is correct, then Chron E23r that lies below the extinction level must be Norian, and thus, if Marzoli's magnetostratigraphic correlations are also correct, the Moroccan basalts, if we believe their short duration, would be Norian and have nothing at all to do with the TriassicJurassic boundary. However, Kozur and Weems (2005) also argue that the strata between the oldest CAMP lavas in the Culpeper basin correlate to the Upper Lilstock Formation in the St. Audrie's Section which lies in the upper part of the "initial" isotopic excursion of Hesselbo et al. (2002) which could be, depending on the decision of where the GSSP for the boundary is placed, by definition, Jurassic or latest Triassic (Rhaetian). If both correlations are true and the Moroccan basalt reverse units correlate to Newark polarity zone E23r, than the CAMP basalts would minimally span all of the Rhaetian, agreeing with the biostratigraphic arguments of Lucas and Tanner (2007). This would then imply the short duration of the CAMP is an illusion and the ${ }^{40} \mathrm{Ar} /{ }^{39} \mathrm{Ar}$ ages are inaccurate (as opposed to simply 
imprecise). The bottom line is that the conchostracan correlations are anomalous and not consistent with any of Marzoli et al.'s arguments.

\section{Cyclostratigraphy}

Marzoli et al. (2008-this volume) question the validity of the cyclostratigraphic arguments of our refinement of the duration of the CAMP. They provide no data to refute our hypothesis, however, and provide only vague statements about possible incompleteness and differences in accumulation rate. If there is something specifically wrong with the cyclostratigraphy, it is their burden to say specifically what it is. They do however, make a specific statement that we have misidentified the stratigraphic position of the hydrobiid gastropodbearing unit near Sidi Rahhal. Some of us (PEO and MET) visited the outcrops in question again in October, 2007, and can unambiguously state that Marzoli et al. (2008-this volume) are incorrect in their assertion that these snail-bearing carbonates belong to strata above the CHA upper basalt unit, and we provide a photograph and measured section to support our stratigraphy (Fig. 1). There is indeed a carbonate bed directly above the upper basalt formation at this locality. But beneath the underlying upper basalt formation is another, thicker carbonate and red bed succession, in which the hydrobiid and other mollusks occur, which is in turn underlain by a thick succession of basalt with pillow horizons typical of the intermediate formation and then by flows with gabbroid layers, typical of the lower basalt formation. The upper carbonate bed is overlain by a relatively thick red bed unit overlain by a thin flow of the recurrent formation (Fig. 1). It is irrelevant that the sedimentary units are not laterally extensive; the specific successions of beds are repeated between the same flow successions at many locations, with the sedimentary packages thickening and thinning and vanishing on the irregular basalt topography, still maintaining their distinctive stratigraphies, features easily confirmed in outcrop. We hypothesize that this regularity stems from the control of climate upon the sedimentation regimes - you cannot get a lacustrine carbonate unless there is enough water to make a lake!

Marzoli et al. (2008-this volume) also assert without references or evidence that, “... the sediment types and sedimentation rates are quite different for example in Morocco, where lagoonal sedimentation dominates...". There is no convincing evidence that lagoonal sedimentation was present, not to mention dominant, in western Morocco, where in fact the accumulation rates are very similar to those in the exposed Fundy basin (Olsen et al., 2003a). There are no documented marine fossils at all in the strata in question, although there was an abundance of evaporite environments, but for the strata we are discussing the ultimate source of the saline water was likely non-marine based on sulfur isotopes from the evaporates themselves (Atlas province: Holser et al., 1988). The only documented invertebrate fossils that have been found thus far are either exclusively non-marine forms, such as the hydrobiids and conchostracans, or poorly preserved bivalves that could belong to any number of non-marine or marine taxa. We recognize that in eastern Morocco there are definitive marine carbonates interbedded with CAMP basalts with a variety of typical marine mollusks and echinoids, and in the Moroccan Atlantic province on the east, sulfur isotopes suggest a mixed marine and continental source of water for the evaporates (Holser et al., 1988), so it is possible that there were some marine incursions, but these have yet to be documented. We conclude that there is no evidence for lagoonal sedimentation and much evidence against it in the Argana and CHA areas and are in fact nearly identical to those in the Fundy basin in eastern North America.

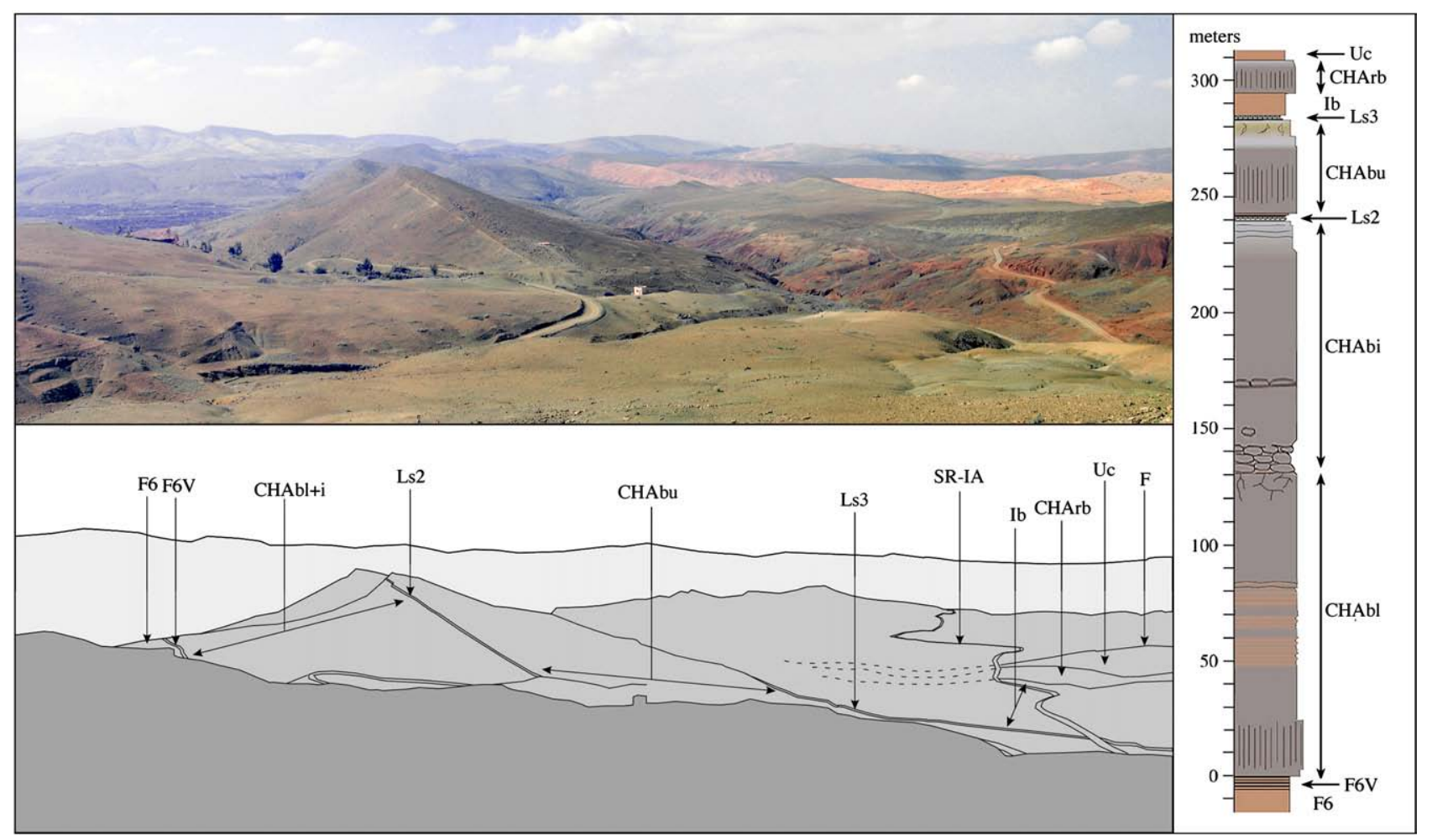

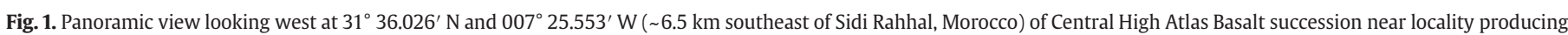

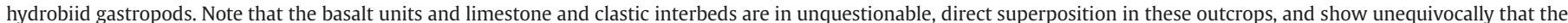

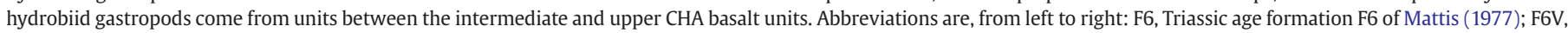

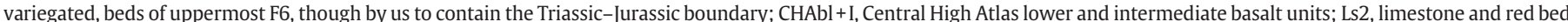

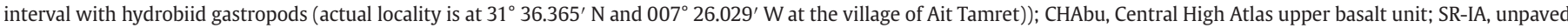

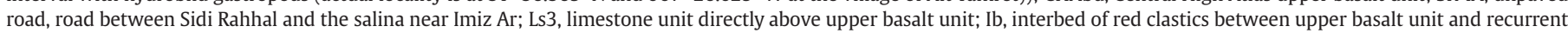
basalt; CHArb, Central High Atlas recurrent basalt unit; Uc, upper red unit with gypsum; F, fault. 


\section{Basalt compositions and volcanostratigraphy}

Marzoli et al. (2008-this volume) state that the, “...geochemical correlations proposed by Whiteside et al. (2007) [based in part on Olsen et al., 2003b] are undermined by mistakes and misinterpretation of the published data.", but the mistakes are not specified, and we do not understand where they occur based on their comments. The diagrams of Olsen et al. (2003b) show original data from Morocco analyzed by Puffer (a coauthor of the 2003b paper) compared with data of Aït Chayeb et al. (1998) and Bertrand (1991). The point of the new data in the Olsen et al. (2003b) paper was to show how similar are data from all of the new samples from all over Morocco, which lie on or very near the HTQ trend as opposed to the HFQ trend (labeled erroneously as LTQ trend) or to the groups 1 or 3 . This includes samples of both lower and upper flow units in the Argana, Kerrouchen, Bou Fekrane, Khemisset, and Iouawen basins. We fail to see how this point is affected by whether or not they were plotted with data of non-CAMP basalts, which were carefully labeled as different and are not our data. In fact, when you plot the $\mathrm{MgO}$ and $\mathrm{TiO}_{2}$ Moroccan data presented here by Marzoli et al. (2008-this volume, their Fig. 1) on our diagram, they lie directly on top of the Moroccan data we collected. In addition, Marzoli et al. (2008-this volume) do not address the $\mathrm{TiO}_{2}$ to $\mathrm{Zr}$ plot on which all of the 2003b Moroccan basalt data lie close to or on the HTQ trend. Again, these comments of Marzoli et al. (2008-this volume) have no bearing on the pertinent conclusion of Olsen et al. (2003b) that the Moroccan CAMP basalts are HTQ and HFTQ basalts that are more similar to the Orange Mountain and Hook Mountain basalts than any other in eastern North America or basalts of other ages seen in Morocco. Of course all of this is also irrelevant to our paper in discussion here.

Of great relevance, however, is the assertion that the CHA lower basalt formation in Morocco has no counterpart in eastern North America. On this point, we point out simply that based on any particular set of comparative data, a subset of North Mountain Basalt data, such as those at Partridge Island, overlap the data from the CHA lower basalt units of Morocco, as pointed out in Deenen et al. (2007a,b), whose main conclusion is that basalts of CHA lower unit chemistry are in fact present in the North Mountain basalt, which shows up most strikingly in cross plots of the rare earth elements. We do not show these data here because they are dealt with in papers in progress by Deenen and coworkers. We are baffled, however by Marzoli et al.'s (2008-this volume) Fig. 1 of $\mathrm{MgO}$ and $\mathrm{TiO}_{2}$ that they assert shows, “...the North Mt. basalts partially overlap in composition only the central High Atlas intermediate or upper basalts, and not the lower basalts." A cursory glance at their figure does not support this contention, because while data from the North Mountain Basalt (5 points) plots over the field of the upper basalt unit, no points unambiguously enter the field of the CHA intermediate basalt, which is what Marzoli et al. (2008-this volume) say it most close resembles, while one North Mountain point plots unambiguously in the CHA lower basalt field. In our paper we plotted the published North Mountain data on $\mathrm{SiO}_{2} \mathrm{vs} \mathrm{TiO}_{2}$ and $\mathrm{SiO}_{2}$ vs $\mathrm{La} / \mathrm{Yb}$ plots because those were the type used by Marzoli et al. (2004) to argue that basalts of CHA lower unit chemistry were not present in eastern North America, and we noted the fact that Marzoli et al. (2008this volume) never mentioned the existence of the North Mountain data in their paper. We did make a typographical error in inverting the labels for the CHA intermediate and upper basalt in our diagram, although that has no effect on any conclusions, and we stand by our reasoning that at least part of the North Mountain basalt is indistinguishable from the CHA lower basalt unit chemistry, a point supported by the independent conclusions of Deenen et al. (2007a,b).

We are also puzzled by the comments of Marzoli et al. (2008-this volume) about our attempt to make explicit the consequences of their hypothesis of correlation for where the carbon isotope excursions of Hesselbo et al. (2002) and others should fall in the CAMP basalt and associated strata. Hypotheses are most valuable when they are posed before the data exist, and that is what we did. Such an explicit prediction of what will be found, a testable hypothesis is, rather than being, "...not an acceptable approach...", is in fact at the core of scientific argument (Popper, 1934). We did this because neither Marzoli et al. (2004) nor Knight et al. (2004) show how their arguments lead to testable hypotheses. Of course, we do not and could not use our hypothesis to support any argument.

All this said, we feel that it is entirely plausible that CAMP eruptions really did start before the biotic turnover, but such eruptions have yet to be unambiguously identified. But it is worth pointing out that correlation does not equal causation as illustrated by the $\mathrm{K}-\mathrm{T}$ debate, where the timing of the $\mathrm{K}-\mathrm{T}$ impact is indisputably within the time of eruption of the Deccan Traps, comparable in magnitude to the CAMP. Yet the timing of the extinctions appears related to the impact, rather than any part of the Deccan that could be predicted a priori. The whole basalt argument could be a "red herring", or perhaps the flow of causation is more complicated than the "either-or" arguments played out here, involving two very catastrophic events instead of one. We remain open to these possibilities.

\section{References}

Aït Chayeb, E.H., Youbi, N., El-Boukhari, A., Bouabdelli, M., Amrhar, M., 1998. Le volcanisme permien et mésozoïque inférieur du bassin d’Argana (Haut-Atlas occidental, Maroc): un magmatisme intraplaque associé à l'ouverture de l'Atlantique central. Journal of African Earth Sciences 26 (4), 499-519.

Bertrand, H., 1991. The Mesozoic tholeiitic province of Northwest Africa; a volcanotectonic record of the early opening of Central Atlantic. In: Kampunzu, A.B., Lubala, T. (Eds.), Magmatism in Extensional Structural Settings; The Phanerozoic African Plate. Springer-Verlag, Berlin, pp. 147-188.

Clement, B.M., 2004. Dependence of the duration of geomagnetic polarity reversals on site latitude. Nature 428, 637-640.

Dam, G., Surlyk, F., 1993. Cyclic sedimentation in a large wave- and storm-dominated anoxic lake; Kap Stewart Formation (Rhaetian - Sinemurian), Jameson Land, East Greenland. In: Posamentier, H.W., Summerhayes, C.P., Haq, B.U., Allen, G.P. (Eds.), Sequence Stratigraphy and Facies Associations. IAS Special Publication, 18, pp. 419-448.

Deenen, M.H.L., Reitsma, M.J., Krijgsman, W., Langereis, C.G., van Bergen, M.J., 2007a. The CAMP controversy, new data from the Argana Basin, Morocco. Geophysical Research Abstracts 9, 06839 (SRef-ID: 1607-7962/gra/EGU2007-A-06839).

Deenen, M.H.L., Reitsma, M.J., Krijgsman, W., Langereis, C.G., van Bergen, M.J., 2007b. The CAMP controversy, new data from the Argana Basin, Morocco. The First MAPG International Convention, Conference and Exhibition, Marrakech Convention Center, October 28-31, 2007, MAPG, p. 41.

Fowell, S.J., Traverse, A., 1995. Palynology and age of the upper Blomidon Formation, Fundy Basin, Nova Scotia. Review of Palaeobotany and Palynology 86 (3-4), 211-233.

Hesselbo, S.P., Robinson, S.A., Surlyk, F., Piasecki, S., 2002. Terrestrial and marine extinction at the Triassic-Jurassic boundary synchronized with major carbon-cycle perturbation: a link to initiation of massive volcanism. Geology 30, 251-254.

Holser, W.T Clement, G.P. Jansa, L.F, Wade, J.A. 1988. Evaporite deposits of the North Atlantic Rift. In: Manspeizer, W. (Ed.), Triassic-Jurassic Rifting, Continental Breakup, and the Formation of the Atlantic Ocean and Passive Margins. B: Dev. Geotecton., 22:41. Elsevier, Amsterdam, pp. 525-556

Hounslow, M.W., Posen, P.E., Warrington, G., 2004. Magnetostratigraphy and biostratigraphy of the Upper Triassic and lowermost Jurassic succession, St. Audrie's Bay. Palaeogeography, Palaeoclimatology, Palaeoecology 213, 331-358.

Kent, D.V., Olsen, P.E., 1999. Astronomically tuned geomagnetic polarity time scale for the Late Triassic. Journal of Geophysical Research 104, 12831-12841.

Kent, D.V., Olsen, P.E., in press. Early Jurassic magnetostratigraphy and paleolatitudes from the Hartford continental rift basin (eastern North America): testing for polarity bias and abrupt polar wander in association with the Central Atlantic Magmatic Province. Journal of Geophysical Research. doi:10.1029/2007JB005407.

Knight, K.B., Nomade, S., Renne, P.R., Marzoli, A., Betrand, H., Youbi, N., 2004. The Central Atlantic magmatic province at the Triassic-Jurassic boundary: paleomagnetic and $40 \mathrm{Ar} / 30 \mathrm{Ar}$ evidence from Morocco for brief, episodic volcanism. Earth and Planetary Science Letters 228, 143-160.

Kozur, H.W. Weems, R.E., 2005. Conchostracan evidence for a late Rhaetian to early Hettangian age for the CAMP volcanic event in the Newark Supergroup, and a Sevatian (late Norian) age for the immediately underlying beds. Hallesches Jahrbuch Geowissenschaft B 27, 21-51.

Lucas, S.G., Tanner, L.H., 2007. The nonmarine Triassic-Jurassic boundary in the Newark Supergroup of eastern North America. Earth-Science Reviews 84, 1-20.

Marzoli, A., Bertrand, H., Knight, K.B., Cirilli, S., Buratti, N., Vérati, C., Nomade, S., Renne, P.R., Youbi, N., Martini, R., Allenbach, K., Neuwerth, R., Rapaille, C., Zaninetti, L., Bellieni, G., 2004. Synchrony of the Central Atlantic magmatic province and the Triassic-Jurassic boundary climatic and biotic crisis. Geology 32, 973-976.

Marzoli, A., Bertrand, H., Knight, K.B., Cirilli, S., Nomade, S., Renne, P.R., Vérati, C., Youbi, N., Martini, R., Bellieni, G., 2008. Synchrony between the Central Atlantic 
magmatic province and the Triassic-Jurassic mass-extinction event? Palaeogeography, Palaeoclimatology, Palaeoecology 262,175-179 (this volume). doi:10.1016/j. palaeo.2006.06.016.

Mattis, A.F., 1977. Nonmarine Triassic sedimentation, Central High Atlas Mountains, Morocco. Journal of Sedimentary Petrology 47, 107-119.

McElwain Popa, M.E., Hesselbo, S.P., Haworth, M., Surlyk, F., 2007. Macroecological responses of terrestrial vegetation to climatic and atmospheric change across the Triassic/Jurassic boundary in East Greenland. Paleobiology 33, 547-573.

Olsen, P.E., Kent, D.V., Et-Touhami, M., 2003a. Chronology and stratigraphy of the Fundy and related Nova Scotia offshore basins and Morocco based on core and outcrop. In: Brown, D. (Ed.), Conventional Core Workshop, Geological Society of America (NE Section) and Atlantic Geoscience Society, Halifax, pp. 51-63.

Olsen, P.E., Kent, D.V., Et-Touhami, M., Puffer, J.H., 2003b. Cyclo-, magneto-, and biostratigraphic constraints on the duration of CAMP event and its relationship to the Triassic-Jurassic boundary. In: Hames, W.E., McHone, J.G., Renne, P.R., Ruppel, C. (Eds.), Central Atlantic Magmatic Province: Insights from Fragments Pangea. Geophysical Monograph Series, vol. 136, pp. 7-32.

Pálfy, J., Mundil, R., 2006. The age of the Triassic/Jurassic boundary: new data and their implications for the extinction and recovery. Volumina Jurassica IV, 294.
Popper, K., 1934. Logik der Forschung. Springer, Vienna.

Schaltegger, U., Guex, J., Bartolini, A., Schoene, B., Ovtcharova, M., 2007. Precise U-Pb age constraints for end-Triassic mass extinction, its correlation to volcanism and Hettangian post-extinction recovery. Earth and Planetary Science Letters 267 (1-2), 266-275.

Schoene, B., Crowley, J.L., Condon, D.J., Schmitz, M.D., Bowring, S.A., 2006. Reassessing the uranium decay constants for geochronology using IDOTIMS U-Pb data Geochimica et Cosmochimica Acta 70, 426-445.

van Veen, P.M., 1995. Time calibration of Triassic/Jurassic microfloral turnover, eastern North America-Comment. Tectonophysics 245 (1-2), 93-95.

Whiteside, J.H., Olsen, P.E., Kent, D.V., Fowell, S.J., Et-Touhami, M., 2007. Synchrony between the Central Atlantic magmatic province and the Triassic-Jurassic mass-extinction event? Palaeogeography, Palaeoclimatology, Palaeoecology 244 345-367.

Yang, Z.Y., Moreau, M.G., Bucher, H., Dommergues, J.L., Trouiller, A., 1996. Hettangian and Sinemurian magnetostratigraphy from Paris Basin. Journal of Geophysical Research-Solid Earth 101, 8025-8042. 